\title{
Tüketicilerin Demografik Özelliklerinin Online Alışveriş Davranışları Üzerine Etkileri
}

\author{
The Effects of the Consumers' Demographic Characteristics on \\ Online Shopping Behavior
}

\author{
Şeniz ÖZHAN ${ }^{1}$, Nevin ALTUĞ ${ }^{2}$
}

\begin{abstract}
ÖZET
Bu çalışmanın amacı, öğretim elemanlarının demografik özellikleri ile online alışveriş yapma sıklıkları ve harcama tutarları arasında bir ilişkinin olup olmadığının belirlenmesi ve öğretim elemanlarının demografik özelliklerine göre, online alışverişe yönelik algıladıkları risk ve faydalar arasında farklılık olup olmadığının incelenmesidir. Araştırmada, Trakya Bölgesi'ndeki üniversitelerde görev yapan öğretim elemanlarından anket yöntemiyle veri toplanmıştır. Verilerin analizi sonucunda, online satın alma davranışı ile katılımcıların gelir düzeyleri arasında anlamlı bir ilişki olduğu ve online alışveriş sürecinin kendisine yönelik algıladıkları faydanın, yaş grupları itibari ile farklı olduğu görülmektedir.
\end{abstract}

Anahtar Kelimeler: Online alışveriş, demografik özellikler, online alışveriş davranışı, öğretim elemanları.

\section{GiRiş}

1990'ların başında internetin ticarileşmesi ile online alışveriş artan bir hızda tüketiciler tarafından kullanılmaya başlanmıştır. Küresel bir ortam olan internet, işletmenin müşterileri ve çalışanları ile coğrafya, zaman ve yerden kaynaklanan birçok iletişim engelini ortadan kaldırmaktadır. Özellikle, sınır ötesi bilgi akışı ve işlemler daha kolay yerine getirilebilmektedir ( $Y u$, 2006). İnternet ve ilişkili teknolojileri sayesinde hem bireyler hem de işletmeler sadece tek bir dokunuşla sohbet edebilme, sipariş takibi yapabilme, mal ve hizmet satın alabilme, potansiyel bir müşterinin kredibilitesini araştırabilme, işletmenin mali durumunu yönetebilme ve daha fazlasını yapabilme olanağına kavuşmuştur (Ugrin vd, 2007). Internetin etkileşim ve izleme yeteneği, iyi telekomünikasyon altyapısı ile özellikle gelişmiş ülkeler için, minimum maliyetle özel uyarlanmış pazarlama sağlamaktadır (Teo ve Tan, 2002).

Satın alınacak ürün hakkında bilgi toplanması, geleneksel ticaret yöntemlerinde firmalar ile görüşülerek, dergiler veya kataloglar incelenerek gerçekleş-

\begin{abstract}
The aim of this study is to determine if there is a relationship between the demographic characteristics of the academic staff and their frequency of online shopping and spending amounts and in order to examine whether there are differences or not in terms of the perceived risks and benefits for online shopping according to their demographical characteristics. In the study, the data were obtained from the academic staff working at the universities located in Thrace Region through the method of questionnaire. As a result of the data analysis, it is seen that there is a significant relationship between the online shopping behavior and the income levels of the participants and the perceived benefits of online shopping process against itself vary according to different age groups.
\end{abstract}

Keywords: Online Shopping, Demographic Characteristics, Online Shopping Behavior, Academic Staff.

tirilmektedir. Oysa e-ticarette bilgi, web sayfaları üzerinde ürün veya hizmet pazarlayan kurumların web sitelerinden rahatlıkla elde edilebilmektedir (Elibol ve Kesici, 2010). Fiziksel alışveriş faaliyetleri yaparak zaman harcamak yerine, tüketiciler online alışveriş yapmayı daha kolay ve daha keyifli bulmaktadırlar. Günümüzde internet üzerinden birçok çeşit mal ve hizmet satın alınabilmektedir. Online satın almanın artan trendi ile, artan sayıda şirket, bu kervana katılmayı avantajlı bulmakta ve tüketicilerine online alışverişin kolaylığını sunmaktadır. Aksi takdirde, kendilerini o yönde hızla ilerleyen çok sayıdaki rakiplerine satışlarını kaptırırken bulacaklardır (Kau vd., 2003).

Internetin bir alışveriş kanalı olarak çok sayıda tüketici tarafından kullanılması ve işletmelerin tüketicilerin online alışveriş davranışlarını anlama ve tahmin etme ihtiyacı bu çalışmanın ana nedenidir. Bunun yanında literatürde tüketicilerin online alışveriş davranışlarını araştıran çok sayıda çalışma olmasına karşın, çalışmanın örneğini oluşturan öğretim elemanlarının online alışveriş davranışlarını inceleyen araştırma sayısı azdır. Bu da çalışmanın özgünlüğünü arttırmak-

\footnotetext{
1 Öğr. Gör. Dr., Namık Kemal Üniversitesi Çorlu Meslek Yüksekokulu İşletme Yönetimi

${ }^{2}$ Yrd. Doç. Dr. ,Trakya Üniversitesi İktisadi ve İdari Bilimler Fakültesi İşletme Bölümü Üretim Yönetimi ve Pazarlama A.B.D.
} 
tadır. Çalışmada öğretim elemanlarının demografik özellikleri ile online alışveriş yapma sıklıkları ve harcama tutarları arasında bir ilişkinin olup olmadığının belirlenmesi ve öğretim elemanlarının demografik özelliklerine göre, online alışverişe yönelik algıladıkları risk ve faydalar arasında farklılık olup olmadığının ortaya konması amaçlanmıştır. Buna göre araştırmada yanıtlanmak istenen sorular şunlardır:

- Öğretim elemanlarının demografik özellikleri ile online alışveriş yapma sıklıkları arasında bir ilişki var mıdır?

- Öğretim elemanlarının demografik özellikleri ile harcama tutarları arasında bir ilişki var mıdır?

- Öğretim elemanlarının demografik özellikleri ile online alışverişe yönelik risk algılamaları arasında bir farklılık var mıdır?

- Öğretim elemanlarının demografik özellikleri ile online alışverişe yönelik fayda algılamaları arasında bir farklılık var mıdır?

\section{LITERATÜR ÖZETi}

Online alışveriş araştırmacılara tüketici davranışları ve karar verme konusunda bilgi kaynağı sağlamaktadır. 1990'lı yılların sonlarından itibaren, bilim adamlarının yaptıkları çalışmalar, internetin tüketimi nasıl değiştirdiği ve bu değiş̧ikliği kolaylaştırıc faktörler üzerinedir (Hannah ve Lybecker, 2010). Internet araştırmacılara kullanıcıların bilgi toplama ve satın alma davranışlarını inceleme imkanı tanımaktadır. Internet tarafından sağlanan yöntemleri uygulayarak araştırmacılar, daha önce araştırma için kolayca erişilebilir olmayan kullanıcıların davranışlarını birçok açıdan inceleyebilmektedir (Rishi, 2008). Internet araştırmacılara bu olanakları sağlarken tüketicilere kolayca bilgi elde edebilme, derinlemesine araştırma ve ürün karşılaştırmaları yapabilme, çeşitli perakendecilerin sunumlarını hızlı, kolay ve ucuz bir şekilde değerlendirebilme gibi yararları geniş bir yelpazede sunabilmektedir (Bagdoniene ve Zemblyte, 2009). Tüketicilerin internet üzerinden yaptıkları bir araştırma satın alma ile sonuçlanmasa da, bilgi toplama gücünden dolayı kullanılmaktadır. Tüketicilerin bilgi toplamak için interneti kullanması da online alışverişten algılanan riski azaltırken, online satın alma olasılığını arttırmaktadır (Liu ve Forsythe, 2010).

Online alışveriş, satıcı ve alıcı arasında birebir etkileşim olmaması bakımından geleneksel alışveriş ortamından bir hayli farklı; işletmelere farkı coğrafyalara dağılmış tüketicilere kolayca ulaşabilmesine olanak tanıması açısından; tüketicilere de özellikle zaman kazandırma ve kolaylık bakımından fayda sağlayan bir alışveriş ortamıdır (Algür ve Cengiz, 2011). Online alışverişin sağladığı faydaların başında fiyat avantajı gelmektedir. Online mağaza sanal olduğundan kira giderleri düşüktür. Daralan tedarik zinciri de mal ve hizmetlerin fiyatını düşürmektedir. İkincisi, ürün bilgisi avantajlarıdır. Geleneksel mağazalar ne kadar büyük olursa olsunlar, ürün içeriği ile ilgili sağladıkları bilgi sınırlıdır. Tüketiciler satın almak istedikleri ürünlerle ilgili bilgileri öğrenmek için mağazalara gitmek zorundadırlar. Oysa internet ortamında tüketiciler malları görüntüleyebilir ve satın alma kararı vermeden önce mal ve hizmetlerle ilgili tüm bilgileri öğrenebilirler. Üçüncüsü ise, tüketicilerin mal tedarikçileri ile online etkileşimde bulunabilme imkanına sahip olmalarıdır (Su ve Huang, 2011).

Araştırmalar, bazı kimselerin online alışveriş yaparken, bazılarının bunu tercih etmediğini ve diğer bazı kimselerin de internet üzerinden satın almak istedikleri mal ve hizmet ile ilgili bilgi toplamakla yetinip, bu mal ve hizmetleri mağazalardan geleneksel yöntemler ile almayı tercih ettiklerini göstermektedir. Dolayısıyla internet de dahil olmak üzere birçok farklı pazarlama kanalından tüketicilere ulaşan işletmelerin, online alışveriş yapan veya yapmayan tüketicilerin bu davranışlarının nedenlerini bilmeleri, tüketicilerinin istek ve ihtiyaçlarına cevap verebilmeleri açısından gerekli ve önemlidir. Ayrıca, insanların, teknoloji kullanma konusundaki tavır, düşünce ve önyargılarının, online faaliyet gösteren işletmelerin web sitesi dizaynından, online reklam, ürün farklılaştırma ve dağıtım stratejilerine kadar verecekleri pek çok yönetsel ve teknolojik stratejik kararda yol gösterici olacaktır (Turan, 2008).

Demografik özellikler ve bunların psikolojik etkenleri internet üzerinden satın alma olasııı̆ını önemli ölçüde etkilemektedir (Akhter, 2003). Akman ve Mishra (2010) Türkiye'de farklı sektörlerdeki çalışanların günlük internet kullanım profili üzerinde cinsiyet, yaş ve gelir etkisini inceleyen çalışmalarında iletişim, e-posta, sohbet, bilgi erişim, yükleme, eğlence vb. amaçlı günlük internet kullanımında cinsiyet ve yaşın etkili olduğu ancak gelirin etkili olmadığı tespit edilmiştir.

Porter ve Donthu (2006) ise, yaptıkları çalışmada tüketicilerin internet konusundaki algılarının demografik özelliklere göre değişiklik gösterdiğini belirlemişlerdir. İnternet kullanımına doğru tutumun yaş, eğitim ve gelir durumuna göre önemli ölçüde farklılık gösterdiği sonucuna varmışlardır. Çalışma yaşlı ve daha az eğitimli kişiler internetin kullanım kolaylığını daha düşük algılarken, düşük gelirli bireylerin interneti daha pahalı olarak algıladıkları ve yaşlı bireylerin internet ile ilişkili birden fazla erişim engeli algıladıklarını göstermiştir. Yine Hills ve Argyle (2003) tarafından yapılan çalışmada cinsiyet ve yaş değişkenleri ile 
internet kullanımı üzerinde durulmuştur. Buna göre; benzer şekilde, erkeklerin kadınlardan ve gençlerin yaşılıardan daha fazla interneti kullandıkları belirlenmiştir. Zhang (2005) yaptığı çalışmada daha genç ve daha eğitimli kişilerin interneti daha faydalı bulduğunu ve daha rahat kullandıklarını göstermiştir. Potosky (2007)'de yaptığı çalışmada internet bilgisi ve demografik değişkenler arasındaki ilişki üzerinde durmuştur. Buna göre, kadınlar erkeklere göre ve yaşlı katılımcılar genç katılımcılara göre internet konusunda daha az bilgi sahibidir.

Pazarlamacılar pazarı bölümlere ayırmak ve etkili stratejiler geliştirmek için demografik farklılıkların öneminin uzun zamandır farkındadır. Cinsiyet her zaman önemli bir demografik değişken olmuş; internet kullanımı ve satın alma konusunda cinsiyet farklılıklarının incelendiği çok sayıda çalışma yapılmıştır (Sebastianelli vd., 2008). Örneğin, Hasan (2010) yaptığı çalışmada online alışveriş tutumunun bilişsel, duygusal ve tutumsal olmak üzere üç farklı bileşenini tanımlamaktadır ve bu tutumsal bileşenlerin cinsiyete göre anlamlı farklılıklar göstereceğini ortaya koymuştur. Cyr ve Bonanni (2005) ise yaptıkları araştırmada alışveriş güvenliği, tercih edilen web sitesinin tasarım öğeleri, güvenilirliği, memnuniyet ve sadakate yönelik tutumlar açısından cinsiyetler arasında farklılık olup olmadığını tespit etmeye çalışmışlardır. Buna göre web sitesinden duyulan memnuniyet ve web sitesinin bilgi, navigasyon ve görsel tasarım algılamaları arasında cinsiyete göre farklııklar olduğunu belirlemişlerdir. Slyke vd. (2002) yaptıkları çalışmada erkeklerin alışveriş yapmak için interneti kullanma olasılığının daha yüksek olduğunu ve erkeklerin online alışveriş özellikleri algılamalarının kadınlardan daha olumlu olduğu sonucuna varmışlardır. Erkeklerin online alışverişin uygunluk, göreceli fayda, kanıtlanabilirlik ve güvenilirlik algılaması kadınlardan daha yüksek ve karmaşıklık algılamasının da daha düşük olduğu saptanmıştır. Özgüven (2011) yaptığı çalışmada tüketicilerin online alışverişe karşı tutumlarının cinsiyete göre farklılık gösterdiğini saptamıştır. Araştırmada kadınların daha fazla online alışveriş yapmakta ve ilgilenmekte oldukları sonucuna varılmıştır.

Shahrokh vd. (2012)'nin İranlı öğrenciler üzerinde yaptıkları çalışmada cinsiyet ve online alışveriş niyeti arasında anlamlı bir ilişki bulunmuştur. Buna göre erkek öğrencilerin online alışverişe daha niyetli oldukları sonucuna ulaşılmıştır. Benzer şekilde Jain ve Jain (2011), Richards ve Shen (2006) ve Akhter (2003)'de yaptıkları çalışmalarda erkeklerin kadınlardan daha fazla online alışveriş yapma eğiliminde olduğu sonucuna varmışlardır. Bu çalışma sonuçlarına göre, akademik personelin online alışveriş yapma sıklığı ile cinsiyetleri arasında anlamlı bir ilişki olması beklenmektedir.

$H_{1}$ : Akademik personelin online alışveriş yapma sıkIığı ile katılımcıların cinsiyetleri arasında istatistiksel açıdan anlamlı bir ilişki vardır.

Yaş da cinsiyet gibi bir kişinin online alışveriş yapma niyetinin önemli bir belirleyicisidir. Özgüven (2011) yaptığı çalışmada tüketicilerin online alışveriş tutumlarının yaşa göre farklılık gösterdiğini ve online alışverişin daha fazla genç tüketiciler tarafından tercih edildiğini belirlemiş̧ir. Yine Akhter (2003)'de yaptığı çalışmada genç tüketicilerin yaşlılara göre online alışveriş yapma olasılıklarının daha yüksek olduğunu belirlemiştir. Literatürdeki bu ve benzer çalışmalardan yola çıkarak akademik personelin online alışveriş yapma sıklığı ile yaşları arasında anlamlı bir ilişki olacağı düşünülmektedir.

$H_{2}$ : Akademik personelin online alışveriş yapma sıklığı ile katılımcıların yaşları arasında istatistiksel açıdan anlamlı bir ilişki vardır.

Literatürde eğitimin online alışveriş davranışında etkili olan değişkenlerden olduğu yönünde bulgulara rastlanmıştır. Örneğin, Özgüven (2011) yaptığı çalışmada tüketicilerin online alışveriş tutumlarının eğitim durumlarına göre farklılık gösterdiği sonucuna varmıştır. Lisans ve lisansüstü mezunu olan kişilerin online alışverişe daha yatkın olduğunu, online alışverişin en düşük düzeyde ortaokul mezunu kişiler tarafından tercih edildiğini tespit etmişlerdir. Yine Candan ve Kurtuluş (2010), Akhter (2003), Jain ve Jain (2011) yaptıkları çalışmada online alışveriş yapanların çoğunlukla eğitim düzeyi yüksek kişiler olduğu sonucuna varmışlardır. Roman (2010)'da yaptığı çaIışmada online alışverişten duyulan memnuniyet ve online alışverişte yaşanabilecek aldatılma durumları üzerinde eğitimin etkisinin yaş ve cinsiyet gibi diğer demografik değişkenlerden daha fazla olduğu sonucuna varmıştır.

Benzer şekilde, Shahrokh vd. (2012)'nin İranlı öğrenciler üzerinde yaptıkları çalışmada eğitim düzeyi ve online alışveriş niyeti arasında anlamlı bir ilişki bulunmuştur. Eğitim düzeyi yüksek olan öğrencilerin online alışveriş konusunda daha bilgili olduğu ve buna ek olarak, doktora öğrencilerinin online alışverişe daha niyetli olduğu sonucuna varmışlardır. Bu yüzden akademik personelin online alışveriş yapma sıklığı ile eğitim düzeyleri arasında anlamlı bir ilişki olması beklenmektedir.

$H_{3}$ : Akademik personelin online alışveriş yapma sıklığı ile katılımcıların eğitim düzeyleri arasında istatistiksel açıdan anlamlı bir ilişki vardır. 
Gelir de pek çok çalışmada online alışveriş yapma eğiliminin önemli bir belirleyicisi olarak tespit edilmiştir. Örneğin, Candan ve Kurtuluş (2010) yaptıkları çalışmada bireylerin online alışveriş yapma durumları ile gelirleri arasında oldukça anlamlı bir ilişki tespit etmişlerdir. Cevaplayıcıların gelir düzeyi arttıkça online alışveriş yapma eğilimleri ile online alışveriş için ayrılan aylık ortalama miktarı da artmaktadır. Akther (2003) ve Jain ve Jain (2011)'de yaptıkları çalışmalarda benzer sonuçlara ulaşmışlardır. Buna göre gelir düzeyi yüksek kimselerin gelir düzeyi düşük kimselere göre online alışveriş yapma olasılıkları daha yüksektir. Benzer şekilde Richards ve Shen (2006)'da yaptıkları çalışmada bireysel ve aile geliri yüksek kimselerin düşük olanlara göre online alışveriş yapma eğiliminin daha yüksek olduğu sonucuna varmışlardır. Bu sebeple, akademik personelin online alışveriş yapma sıklığı ile gelirleri arasında anlamlı bir ilişki olması beklenebilir.

$\mathrm{H}_{4}$ : Akademik personelin online alışveriş yapma sıkığı ile katılımcıların gelirleri arasında istatistiksel açıdan anlamlı bir ilişki vardır.

Cinsiyet bir kişinin online alışverişi riskli olarak algılayıp algılamamada da önemli bir belirleyici olabilmektedir. Örneğin, Santana ve Loureiro (2010) yaptıkları çalışmada kadınların online alışverişi erkeklere göre daha riskli buldukları sonucuna ulaşmışlardır. Forsythe ve Shi (2003)'de yaptıkları çalışmada kadınların erkeklere göre online alışverişte daha fazla finansal risk algıladıklarını belirlemişlerdir. Benzer şekilde Dillon ve Reif (2004)'in yaptıkları çalışmada erkeklerin kadınlara göre ödeme şekilleri, gizlilik ve kredi kartı güvenliği gibi tüketici risklerinden daha az etkilendiği bulunmuştur. Bu yüzden akademik personelin cinsiyetleri ile online satın alma davranışından algıladıkları risk arasında anlamlı bir farklılık olması beklenmektedir.

$H_{5}$ : Online alışveriş yapan akademik personelin cinsiyetlerine göre online satın alma davranışından algıladıkları risk arasında istatistiksel açıdan anlamlı bir farklılık vardır.

Literatürde cinsiyet ile online alışverişin algılanan faydası arasında farklılık olduğu yönünde bulgular tespit edilmiştir. Örneğin, Slyke vd. (2002) yaptıkları çalışmada erkeklerin online alışverişi kadınlardan daha faydalı olarak algıladığını ortaya koymuşlardır. Bu sebeple akademik personelin cinsiyetlerine göre online satın alma davranışından algıladıkları fayda arasında anlamlı bir farklılık olması beklenebilir.

$H_{6}$ : Online alışveriş yapan akademik personelin cinsiyetlerine göre online satın alma davranışından algıladıkları fayda arasında istatistiksel açıdan anlamlı bir farklılık vardır.
Yaş pek çok çalışmada online alışverişin riskli olarak algılanıp algılanmamasının temel belirleyicisi olarak bulunmuştur. Gençler risk almaya daha yatkındır. Yaşlı tüketiciler, internetten alışverişe çok fazla güvenmemekte ve satın aldığı malda yanılabileceğini ya da aldatılabileceğini düşünmektedir. Bu nedenle, interneti kullansalar bile, online alışverişe ön yargılı yaklaşmaktadırlar (Özgüven, 2011). Örneğin, Forsythe ve Shi (2003) yaptıkları çalışmada gençlerin daha az ürün-performans riski ve finansal risk algıladıklarını buna karşııık yaşılıarın daha az zaman/kolaylık riski daha fazla psikolojik risk algıladıklarını belirlemişlerdir. Bu yüzden akademik personelin yaşına göre online satın alma davranışından algıladıkları risk arasında anlamlı bir farklılık olması beklenmektedir.

$H_{7}$ : Online alışveriş yapan akademik personelin yaşına göre online satın alma davranışından algıladıkları risk arasında istatistiksel açıdan anlamlı bir farklılık vardır.

Literatürde genç tüketicilerin online alışverişi daha faydalı bulduğunu destekleyen çok sayıda çaış̧ma mevcuttur. Örneğin Sorce vd. (2005) yaptıkları çalışmada genç tüketicilerin yaşı tüketicilere göre internetten ürünler hakkında daha fazla bilgi topladıkları ve genç tüketicilerin yaşlı tüketicilere göre online alışverişi daha faydalı bulduklarını belirlemişlerdir. Benzer şekilde Yang (2005) yaptığı çalışmada yaşın mobil ticaretin algılanan faydasını olumsuz yönde etkilediğini belirlemiştir. Bu sebeple akademik personelin yaşına göre online satın alma davranışından algıladıkları fayda arasında anlamlı bir farklılık olması beklenebilir.

$H_{8}$ : Online alışveriş yapan akademik personelin yaşına göre online satın alma davranışından algıladıkları fayda arasında istatistiksel açıdan anlamlı bir farklılık vardır.

Literatürde eğitim ile online satın alma davranışından algılanan risk arasında farklılık olduğu yönünde bulgulara rastlanmıştır. Örneğin, Liu ve Forsythe (2010) yaptıkları çalışmada ürüne ilişkin risklerin eğitim düzeyi düşük kişilerin online satın alma davranışlarını azalttığını belirlemişlerdir. Bu yüzden akademik personelin eğitim düzeyine göre online satın alma davranışından algıladıkları risk arasında anlamlı bir farklılık olması beklenebilir.

$H_{g}$ : Online alışveriş yapan akademik personelin eğitim düzeyine göre online satın alma davranışından algıladıkları risk arasında istatistiksel açıdan anlamlı bir farklılık vardır.

Eğitim online alışverişin faydalı olarak algılanıp algılanmaması üzerinde etkilidir. Eğitim düzeyi yüksek kişiler, online alışverişin ödeme koşulları, kampanyalar, web sitelerinin güvenlik önlemleri, müşteri hizmetleri, iade imkanları ve tüketicilere tanınan di- 
ğer haklar konusunda daha fazla bilgiye sahiptirler. Bu yüzden online alışverişe daha rahat ve güvenerek yönelebilmektedirler (Özgüven, 2011). Örneğin Yang (2005) yaptığı çalışmada, eğitimin mobil ticaretin algılanan faydasını etkilediğini belirlemiştir. Bu sebeple akademik personelin eğitim düzeyine göre online satın alma davranışından algıladıkları fayda arasında anlamlı bir farklııı olması beklenmektedir.

$H_{10}$ : Online alışveriş yapan akademik personelin eğitim düzeyine göre online satın alma davranışından algıladıkları fayda arasında istatistiksel açıdan anlamlı bir farklılık vardır.

Gelir pek çok çalışmada online alışverişin risk algılamasında etkili bir değişken olarak bulunmuştur. Gelir düzeyi düşük kişiler, sınırlı bütçeleri ile ürünleri deneyerek, görerek ve beş duyu organı ile algılayarak satın almayı tercih etmekte; risk almaktan kaçınmaktadırlar (Özgüven, 2011). Liu ve Forsythe (2010) yaptıkları çalışmada ürüne ilişkin risklerin gelir düzeyi düşük kişilerin online satın alma davranışlarını azalttığını belirlemişlerdir. Bu yüzden akademik personelin gelirine göre online satın alma davranışından algıladıkları risk arasında anlamlı bir farklılık olması beklenmektedir.

$H_{11}$ : Online alışveriş yapan akademik personelin gelirine göre online satın alma davranışından algıladıkları risk arasında istatistiksel açıdan anlamlı bir farklılık vardir.

Literatürde gelir ile online satın alma davranışından algılanan fayda arasında farklılık olduğu yönünde bulgulara rastlanmıştır. Örneğin Kurtuldu ve Karataş (2005) yaptıkları çalışmada gelir düzeyi arttıkça kullanıcıların internet üzerinden gerçekleştirilen bankacılık işlemlerini daha uygun bulduklarını ve işlemlerini internet yoluyla gerçekleştirmeye özen gösterdiklerini belirlemişlerdir. Bu yüzden akademik personelin gelirine göre online satın alma davranışından algıladıkları fayda arasında anlamlı bir farklılık olması beklenmektedir.

$H_{12}$ : Online alışveriş yapan akademik personelin gelirine göre online satın alma davranışından algıladıkları fayda arasında istatistiksel açıdan anlamlı bir farkılık vardır.

\section{METODOLOJI}

Araştırma yöntemi olarak öncelikle literatür taramasına yer verilmiştir. Elde edilen bilgilere dayanarak, alan araştırması kapsamında anket yöntemi kullanılmıştır. Anket formu Özen'in (2007) araştırmasında kullandığı soru formundan derlenmiştir. Araştırma modeli ve değişkenleri Şekil 1'de olduğu gibidir:

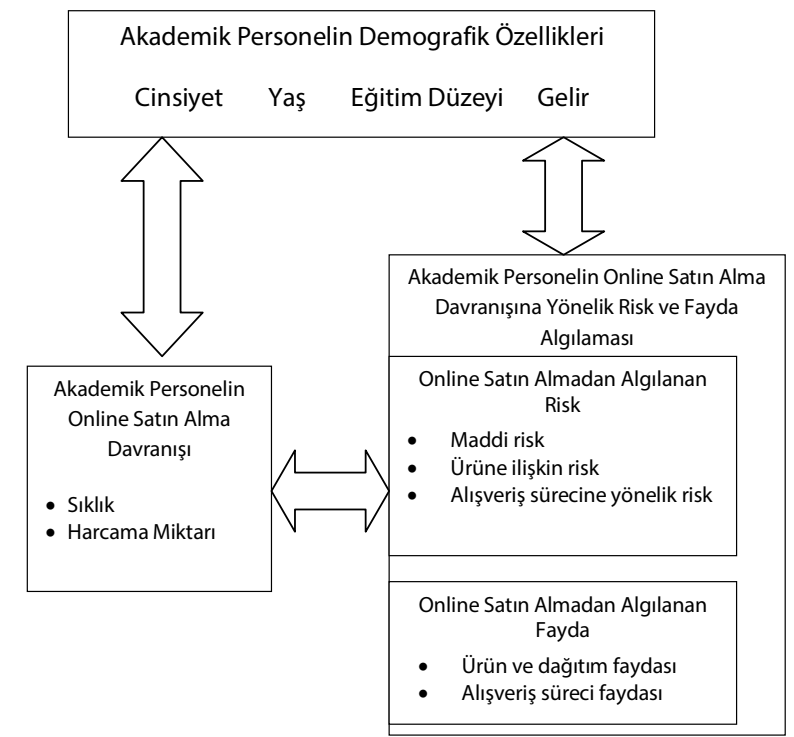

Şekil 1. Araştırma Modeli ve Değişkenleri

Şekil 1.'deki araştırma modelinden de görüleceği üzere, mevcut araştırma, değişkenler arasındaki ilişkileri tanımlamayı ve ortaya koymayı amaçlayan bir tanımlayıcı araştırmadır (Kurtuluş, 2008: 132.). Araştırmaya konu olan değişkenler, üç temel başılık altında ele alınabilir. Akademik personelin online satın alma davranışı, satın alma miktarı ve sıklığı ile ölçülürken; online satın alma davranışından algılanan risk 5 'li likert ölçeği ( $1=$ Kesinlikle Katılmıyorum, 5=Kesinlikle Katılıyorum) şeklinde 14 değişkenden oluşan ölçek; online satın alma davranışından algılanan fayda ise 5 'li likert ölçeği ( $1=$ Kesinlikle Katılmıyorum, 5=Kesinlikle Katılıyorum) şeklinde 17 değişkenden oluşan ölçek aracılığıyla ölçülmüştür. Online satın alma davranışından algılanan risk ve online satın alma davranışından algılanan fayda Özen'in (2007) çalışmasında Forsythe, Liu, Shannon ve Gardner (2006) ve Bhatnagar ve Ghose (2004)'un çalışmalarından derleyerek oluşturduğu ölçekler yardımıyla ölçülmüştür. Demografik özellikler ise cinsiyet, yaş, eğitim düzeyi ve gelir şeklinde 4 adet değişken yardımıyla ölçülmüştür.

Araştırmanın ana kütlesi Türkiye'de Trakya Bölgesi'nde yer alan üç üniversitede görev yapan akademik personeldir. Trakya Bölgesi'nde yer alan Trakya, Kırklareli ve Namık Kemal Üniversiteleri'nden kolayda örnekleme yoluyla oluşturulan bir örneklem üzerinde çalışılmıştır. Tesadüfi olmayan örnekleme yöntemlerinde örnek büyüklüğünü belirlemede, kullanılacak olan analizler etkili olmaktadır. Araştırmada kullanılan ölçekler ile daha rahat çalışabilmek için keşfedici faktör analizinden yararlanılacağı için, bu analizin gerektirdiği en küçük örnek büyüklüğü gözönüne alınmıştır. Hair vd. (1998:99)'ne göre faktör analizi için kabul edilebilir en küçük örnek büyüklüğü, analize dahil 
edilecek değişken sayısının on katı büyüklüğünde bir örneklemdir. Akademik personelin online satın alma davranışına yönelik algıladıkları risk ve faydanın belirlenmesinde toplam 31 değişkenden yararlanıldığı için minimum örnek büyüklüğü 310 olarak belirlenmiş ancak, daha büyük bir örneğe ulaşılmaya çalışmıştır. Bilgi toplama aracı ve yöntemi olarak yüz yüze anket yönteminden yararlanılmıştır.

Anket formu üç temel bölümden oluşmaktadır. Birinci bölümde, nominal biçiminde internet kullanım süresi, internet kullanma sıklığı, online alışveriş yapıp yapmama, online alışveriş sıklığı ve online alışverişte yapılan harcama miktarını belirlemeye yönelik sorular yer almaktadır. İkinci bölüm ise online satın alma davranışına yönelik algılanan risk ve faydaları belirlemeye yönelik 5'li likert ölçeği biçiminde hazırlanmış soruların yer aldığı bölümken; üçüncü ve son bölüm ise demografik değişkenlerin yer aldığı bölümdür. Demografik değişkenlerden yaş değişkeni açık uçlu sorulmuş ve sonrasında sınıflandırılma yapılarak nominal ölçek haline getirilmiştir. Kalan diğer tüm demografik değişkenler ise nominal ölçek aracılığıyla ölçülmüştür. Sonuç olarak 520 kişiye anket uygulanmıştır. Anketlerden eksik ve hatalı doldurulanlar elendiğinde 509 adet anket analizlerde kullanılmıştır.

\section{BULGULAR}

\subsection{Demografik Yapıya iliş̧kin Bulgular}

Tablo 1'de araştırmaya katılan akademik personelin demografik yapılarına ait özellikler yer almaktadır.

Tablo 1. Akademik Personelin Demografik Özellikleri

\begin{tabular}{|l|c|c|l|c|c|}
\hline \multicolumn{1}{|c|}{ Değişkenler } & Frekans & Yüzde $\%$ & \multicolumn{1}{c|}{ Değişkenler } & Frekans & Yüzde $\%$ \\
\hline Cinsiyet & & & Eğitim & & \\
\hline Kadın & 231 & 45,4 & Lisans & 71 & 13,9 \\
\hline Erkek & 278 & 54,6 & Yüksek Lisans & 161 & 31,6 \\
\hline Toplam & 509 & 100 & Doktora & 277 & 54,4 \\
\hline Yaş & & & Toplam & 509 & 100 \\
\hline $20-29$ & 77 & 15,1 & Gelir & & \\
\hline $30-39$ & 232 & 45,6 & $1500-2500$ & 239 & 47 \\
\hline $40-49$ & 166 & 32,6 & $2501-3500$ & 92 & 18,1 \\
\hline $50-59$ & 29 & 5,7 & $3501-4500$ & 89 & 17,5 \\
\hline $60-69$ & 5 & 1 & $4501-5500$ & 50 & 9,8 \\
\hline Toplam & 509 & 100 & 5501 ve üzeri & 39 & 7,7 \\
\hline & & & Toplam & 509 & 100 \\
\hline
\end{tabular}

Araştırmaya katılan akademik personelin \% 45,4'ü kadın, \% 54,6'sı erkek katılımcılardan oluşmakta; katılımcıların büyük çoğunluğu 30-39 ve 40-49 yaş gruplarında toplanmaktadır. Araştırmaya katılan akademik personelin çoğunluğunun doktora mezunu olduğu ve yine büyük çoğunluğunun aylık gelirlerinin 1.5002.500 TL arasında olduğu görülmektedir.

Araştırmaya katılan akademik personelin çoğunluğunun 10 yıl ve üzeri süredir internet kullanmakta olduğu ve interneti her gün kullanan katılımcılardan oluştuğu görülmektedir. Online alışveriş yapma durumlarına bakıldığında katılımcıların \% 62,3'ünün online alışveriş yaptıkları; son bir yıl içerisinde büyük çoğunluğunun 1-2 defa ve 3-4 defa alışveriş yaptıkları ve yine büyük çoğunluğun 0-250 TL ve 251-500 TL arasında harcamada bulundukları görülmektedir.

\subsection{Kullanılan Ölçeklerin Güvenilirlik Analizi}

Katılımcıların, online satın almadan algıladıkları riski ortaya koymak için kullanılan, 14 adet değişkenden oluşan ölçeğin içsel tutarlılığını (güvenilirliğini) belirlemek üzere, Cronbach Alpha Güvenilirlik Analizi'nden yararlanılmıştır. Güvenilirlik analizi sonucunda alfa katsayısı 0,712 olarak bulunmuştur.

Katılımcıların, online satın almadan algıladıkları faydayı ortaya koymak için kullanılan, 17 adet değişkenden oluşan ölçeğin alfa katsayısı ise 0.847 olarak bulunmuştur. Hesaplanan her iki alfa değeri de tanımlayıc nitelikteki araştırmalar için kabul edilebilir değeri olan 0,70 değerinin üzerindedir (Hair vd., 1998). Buradan hareketle kullanılan ölçeklerin içsel tutarlılıklarının yüksek olduğu ifade edilebilir. 
Tablo 2. Akademik Personelin İnternet Kullanımı Ille İnternetten Alışveriş Yapma Durumuna Yönelik Bulgular

\begin{tabular}{|l|c|c|l|c|c|}
\hline \multicolumn{1}{|c|}{ Değişkenler } & Frekans & Yüzde \% & \multicolumn{1}{c|}{ Değişkenler } & Frekans & Yüzde \% \\
\hline İnternet Kullanma Süresi & & & $\begin{array}{l}\text { On İki Ayda Internetten } \\
\text { Alışveriş Yapma Miktarı }\end{array}$ & & \\
\hline 2-3 yıl & 3 & 0,6 & $1-2$ defa & 92 & 0,29 \\
\hline $4-5$ yıl & 24 & 4,7 & $3-4$ defa & 85 & 0,27 \\
\hline 6-7 yıl & 69 & 13,6 & $5-6$ defa & 56 & 0,18 \\
\hline 8-9 yıl & 88 & 17,3 & $7-8$ defa & 13 & 0,04 \\
\hline 10 yıl ve üzeri & 325 & 63,9 & $9-10$ defa & 21 & 0,07 \\
\hline Toplam & 509 & 100 & 11 defa ve üzeri & 50 & 0,15 \\
\hline Internet Kullanım Sıklığı & & & Toplam & 317 & 100 \\
\hline Her gün & 470 & 92,3 & $\begin{array}{l}\text { On İki Ayda İnternetten } \\
\text { Alısveriş Yapma Tutarı }\end{array}$ & & \\
\hline Haftada birkaç kez & 37 & 7,3 & $0-250$ TL & 84 & 0,27 \\
\hline Haftada bir kez & 1 & 0,2 & $251-500$ TL & 83 & 0,26 \\
\hline Ayda birkaç kez & 1 & 0,2 & $501-1000$ TL & 55 & 0,17 \\
\hline Toplam & 509 & 100 & $1001-2000$ TL & 53 & 0,17 \\
\hline İnternetten Alısveriş Yapma Durumu & & & $2001-3000$ TL & 22 & 0,07 \\
\hline Evet & 317 & 62,3 & 3001 TL ve üzeri & 20 & 0,06 \\
\hline Hayır & 192 & 37,7 & Toplam & 317 & 100 \\
\hline Toplam & 509 & 100 & & & \\
\hline
\end{tabular}

\subsection{Analiz ve Bulgular}

Katılımcıların, online satın almadan algıladıkları risk ve faydayı ortaya koymak için kullanılan ölçeklerle daha rahat çalışabilmek adına her iki ölçek, varimax rotasyonu kullanılarak ayrı ayrı keşfedici faktör analizlerine tabi tutulmuştur.

Algılanan risk ölçeğine ilişkin uygulanan ilk faktör analizi sonucunda; kararsız yapı gösteren, bir başka ifadeyle farklı faktörler altında birbirine yakın faktör yükleri bulunan, iki değişken çıkarılarak analiz tekrarlanmıştır. Elde edilen nihai faktörler, bu faktörlere ait değişkenlerin faktör yükleri ve her bir faktörün açıkladığı varyans ile güvenilirlikleri Tablo 3'de olduğu gibidir: 
Tablo 3. Online Satın Almadan Algılan Riske İlişkin Faktör Analizi

\begin{tabular}{|c|c|c|c|}
\hline Faktörler ve İçerikleri & \multirow{2}{*}{$\begin{array}{l}\text { Faktör } \\
\text { Yükü }\end{array}$} & \multirow{2}{*}{$\begin{array}{l}\text { Her bir } \\
\text { Faktörün } \\
\text { Açıkladığı } \\
\text { Varyans }\end{array}$} & \multirow{2}{*}{$\begin{array}{c}\text { Her bir } \\
\text { Faktörün } \\
\text { Güvenilirliği }\end{array}$} \\
\hline Maddi Risk & & & \\
\hline İnternetteki satıcılara güvenemem & 0,808 & \multirow{5}{*}{$\% 22,298$} & \multirow{5}{*}{0,786} \\
\hline İnternetteki satıcılardan satın aldığım ürün bana ulaşmazsa diye çekinirim & 0,773 & & \\
\hline $\begin{array}{l}\text { İnternet üzerinden satış yapan firmada kredi kartı bilgilerim güvenli bir şekilde } \\
\text { saklanmaz, başkalarına verilebilir }\end{array}$ & 0,755 & & \\
\hline $\begin{array}{l}\text { İnternet üzerinden sıklıkla alışveriş yapmamamın tek ve en büyük nedeni kredi } \\
\text { kartı bilgilerimi vermek zorunda kalmamdır }\end{array}$ & 0,720 & & \\
\hline $\begin{array}{l}\text { İnternetten, satın aldığım ürününün gerçek miktarından fazla bir bedelle fatura } \\
\text { edilme olasılığı daha yüksektir }\end{array}$ & 0,444 & & \\
\hline \multicolumn{4}{|l|}{ Ürüne Illişkin Risk } \\
\hline İnternetten alacağım giyim ürünlerini üstümde deneme |imkanım yoktur & 0,910 & \multirow{4}{*}{$\% 22,199$} & \multirow{4}{*}{0,685} \\
\hline Satın alacağım ürüne elle dokunma ve yakından inceleme imkanı yoktur & 0,878 & & \\
\hline Giyim ürünlerinde beden ölçüleri bir problem olabilir & 0,819 & & \\
\hline İnternetten satın alacağım ürünün kendisini incelemek mümkün değildir & 0,545 & & \\
\hline \multicolumn{4}{|l|}{ Alışveriş Sürecine Yönelik Risk } \\
\hline Yapmak istediğim alışverişle ilgili uygun web sayfasını bulmak zordur & 0,851 & \multirow{3}{*}{$\% 17,458$} & \multirow{3}{*}{0,707} \\
\hline $\begin{array}{l}\text { İnternetten alacağım ürünlere ilişkin bilgi ve resimlerin bilgisayarımın ekranına } \\
\text { indirilmesi zaman alır }\end{array}$ & 0,804 & & \\
\hline İnternetten sipariş vermek çok karmaşık bir işlemdir & 0,667 & & \\
\hline $\begin{array}{l}\text { Toplam Açıklanan Varyans } \\
\text { KMO Measure of Sampling Adequacy. } \\
\text { Bartlett's Test of Sphericity Approx. Chi-Square } \\
\text { Serbestlik Derecesi } \\
\text { Önem Seviyesi }\end{array}$ & \multicolumn{3}{|c|}{$\begin{array}{c}\% 62,298 \\
0,778 \\
2075,355 \\
66 \\
0,000\end{array}$} \\
\hline
\end{tabular}

Tablo 3 incelendiğinde, KMO değerinin 0,778 ile istenen değer olan 0,50'in üzerinde olduğu görülmektedir (Hair, Anderson, Tahtam ve Black, 2005).

Yine Bartlett test değeri anlamlı olarak bulunmuştur $(p=0,000)$. Böylece eldeki verinin faktör analizi uygulanmasına elverişli olduğu ifade edilebilir. Analiz sonucunda online satın almadan algılanan riskin 3 faktör altında toplandığı, bu üç faktörün ise toplam varyansın \% 62,298'ini açıklayarak, tanımlayıcı nitelikteki araştırmalarda istenen $\% 60^{\prime}$ 'ık değerin üzerinde bir değer sağladığı görülmektedir. Faktörlerin güvenilirlik değerlerine bakıldığında ise bütün faktörlerin güvenilirliklerinin 0,6 ile 0,8 arasında değerler olduğu, bu nedenle yüksek güvenilirliğe sahip faktörler oldukları ifade edilebilir (Kayış, 2008: 405).

Faktörlerin isimlendirilmesi ise içerdikleri değişkenler dikkate alınarak yapılmıştır. Birinci faktörün altında toplanan değişkenler incelendiğinde, bu de- ğişkenlerin maddiyatla ilgili oldukları görülmüş ve bu nedenle ilgili faktörün maddi risk olarak isimlendirilmesinin uygun olacağı düşünülmüştür. İkinci faktör altında toplanan değişkenler incelendiğinde, hepsinin satın alınan ürüne yönelik riskler olduğu ve bu faktörün ürüne ilişkin riskler olarak isimlendirilmesine karar verilmiştir. Son olarak üçüncü faktör ise alışveriş sürecinin kendisine yönelik riskleri içerdiğinden, bu faktör de alışveriş sürecine ilişkin riskler olarak isimlendirilmiştir.

Algılanan fayda ölçeğine ilişkin uygulanan ilk faktör analizi sonucunda; kararsız yapı gösteren veya faktör güvenilirlikleri kabul edilebilir sınırın altında olan değişkenler çıkarılarak analiz tekrarlanmıştır. Elde edilen nihai faktörler, bu faktörlere ait değişkenlerin faktör yükleri ve her bir faktörün açıkladığı varyans ile güvenilirlikleri Tablo 4'te olduğu gibidir: 
Tablo 4. Online Satın Almadan Algılan Faydaya İlişkin Faktör Analizi

\begin{tabular}{|c|c|c|c|}
\hline Faktörler ve i̇çerikleri & Faktör & $\begin{array}{l}\text { Her bir } \\
\text { Faktörün }\end{array}$ & \\
\hline Ürün ve Dağıtım Faydası & & Varyans & Güvenilirliği \\
\hline İnternetteki satıcılar, daha geniş ürün seçeneği sunarlar & 0,821 & \multirow{5}{*}{$\% 35,149$} & \multirow{5}{*}{0,833} \\
\hline İnternetten birçok marka ve mağazaya ulaşabilirim & 0,776 & & \\
\hline İnternette, ürünler hakkında detaylı bilgi edinme imkanı vardır & 0,758 & & \\
\hline İnternetteki satıcılar, daha uygun fiyatlar önerirler & 0,646 & & \\
\hline $\begin{array}{l}\text { İnternet üzerinden alışverişte satın alacağım ürünün özelliklerini } \\
\text { kendime göre seçip belirleyebilirim }\end{array}$ & 0,632 & & \\
\hline $\begin{array}{l}\text { İnternet üzerinden alışveriş, dünyanın her yerindeki ürünlere ulaşma } \\
\text { imkanı verir }\end{array}$ & 0,554 & & \\
\hline \multicolumn{2}{|l|}{ Alışveriş Süreci Faydası } & \multirow{4}{*}{$\% 24,219$} & \multirow{4}{*}{0,715} \\
\hline $\begin{array}{l}\text { İnternet üzerinden alışveriş yaparken ürünü almazsam mağazadaki gibi } \\
\text { mahcup olmam }\end{array}$ & 0,804 & & \\
\hline $\begin{array}{l}\text { Hattın veya elemanların meşgul olması gibi bir durumla internetten alışverişte } \\
\text { karşılaşmam }\end{array}$ & 0,761 & & \\
\hline $\begin{array}{l}\text { İnternet üzerinden alışveriş yaparken beşeri unsurlardan ve insan } \\
\text { kalabalığından kaynaklanan zorluklar yaşamam }\end{array}$ & 0,732 & & \\
\hline $\begin{array}{l}\text { Toplam Açıklanan Varyans } \\
\text { KMO Measure of Sampling Adequacy. } \\
\text { Bartlett's Test of Sphericity Approx. Chi-Square } \\
\text { Serbestlik Derecesi } \\
\text { Önem Seviyesi }\end{array}$ & & $\begin{array}{c}\% 59,367 \\
0,875 \\
967,841 \\
36 \\
0,000\end{array}$ & \\
\hline
\end{tabular}

Tablo 4 incelendiğinde, KMO değerinin 0,875 ile istenen değer olan 0,50'in üzerinde olduğu görülmektedir (Hair, Anderson, Tahtam ve Black, 2005). Yine Bartlett test değeri anlamlı olarak bulunmuştur $(p=0,000)$. Böylece eldeki verinin faktör analizi uygulanmasına elverişli olduğu ifade edilebilir. Analiz sonucunda online satın almadan algılanan faydanın 2 faktör altında toplandığı, bu iki faktörün ise toplam varyansın \% 59,367'sini açıklayarak, tanımlayıcı nitelikteki araştırmalarda istenen \% 60'ık değere çok yakın bir değer sağladığı görülmektedir. Faktörlerin güvenilirlik değerlerine bakıldığında ise yine bütün faktörlerin güvenilirliklerinin 0,6 ile 0,8 arasında değerler olduğu, bu nedenle yüksek güvenilirliğe sahip faktörler oldukları ifade edilebilir (Kayış, 2008: 405).

Faktörlerin isimlendirilmesi yine içerdiği değişkenler esas alınarak yapılmıştır. Birinci faktörün altında toplanan değişkenler incelendiğinde, bu değişkenlerin ürün ve dağıtım ile ilgili oldukları görülmüş ve bu faktörün ürün ve dağıtım faydası olarak isimlendirilmiştir. Íkinci faktör altında toplanan değişkenler incelendiğinde ise söz konusu değişkenlerin hepsinin alışveriş sürecinin kendisine yönelik algılanan faydalar olduğu ve bu nedenle ikinci faktörün alışveriş süreci faydası olarak isimlendirilmesine karar verilmiştir.
$\mathrm{H}_{1}, \mathrm{H}_{2}, \mathrm{H}_{3}$ ve $\mathrm{H}_{4}$ hipotezlerini test etmek için Ki-kare analizinden yararlanılmıştır. Elde edilen sonuçlar özet şekilde Tablo 5 'de olduğu gibidir:

Tablo 5. Demografik Özelliklere Göre Online Satın Alma Davranışına Yönelik Ki-Kare Analizi

\begin{tabular}{|l|c|c|c|}
\hline Değişken & $\mathbf{X}^{\mathbf{2}}$ Değeri & $\begin{array}{c}\text { Serbestlik } \\
\text { Derecesi }\end{array}$ & $\begin{array}{c}\text { Önem } \\
\text { Seviyesi }\end{array}$ \\
\hline Cinsiyet & 8,563 & 5 & 0,128 \\
\hline Yaş & 7,425 & 9 & 0,593 \\
\hline Eğitim & 10,002 & 6 & 0,125 \\
\hline Gelir & 27,356 & 12 & $\mathbf{0 , 0 0 7}$ \\
\hline
\end{tabular}

Tablo 5'den görüldüğü üzere, online satın alma davranışı ile katılımcıların gelir düzeyleri arasında anlamlı bir ilişki olduğu anlaşılmaktadır. Bu nedenle online satın alma davranışı ile gelir düzeyi arasındaki ilişkiyi hesaplamada kullanılan çapraz tablo incelenmiş ve gelir düzeyi arttıkça, online satın alma sayısının da arttığı gözlenmiştir. Dolayısıyla, gelir ile online satın alma sayısı arasında pozitif yönde bir ilişkinin var olduğu ifade edilebilir.

$\mathrm{H}_{5}$ ve $\mathrm{H}_{6}$ hipotezleri için bağımsız $\mathrm{t}$ testlerinden yararlanılmıştır. Sonuçlar özet şekilde Tablo 6'da olduğu gibidir: 
Tablo.6 Cinsiyete Göre Algılanan Risk ve Fayda Arasındaki Farklar

\begin{tabular}{|c|c|c|c|c|c|c|}
\hline Hipotez & Değişken & Cinsiyet & Ortalama & T değeri & $\begin{array}{c}\text { Serbestlik } \\
\text { Derecesi }\end{array}$ & $\begin{array}{c}\text { Önem } \\
\text { Seviyesi }\end{array}$ \\
\hline \multirow{6}{*}{$\mathbf{H}_{5}$} & \multirow{2}{*}{ Maddi Risk } & Kadın & 2,78 & \multirow{2}{*}{0,933} & \multirow{2}{*}{302} & \multirow{2}{*}{0,420} \\
\hline & & Erkek & 2,70 & & & \\
\hline & \multirow{2}{*}{ Ürüne İlişkin Risk } & Kadın & 4,07 & \multirow{2}{*}{$-0,132$} & \multirow{2}{*}{305} & \multirow{2}{*}{0,553} \\
\hline & & Erkek & 4,08 & & & \\
\hline & \multirow{2}{*}{ Alış Veriş Sürecine Yönelik Risk } & Kadın & 2,13 & \multirow{2}{*}{$-0,629$} & \multirow{2}{*}{307} & \multirow{2}{*}{0,621} \\
\hline & & Erkek & 2,18 & & & \\
\hline \multirow{4}{*}{$\mathrm{H}_{6}$} & \multirow{2}{*}{ Ürün ve Dağıtım Faydası } & Kadın & 4,05 & \multirow{2}{*}{$-1,082$} & \multirow{2}{*}{300} & \multirow{2}{*}{0,634} \\
\hline & & Erkek & 4,13 & & & \\
\hline & \multirow{2}{*}{ Alış Veriş Süreci Faydası } & Kadın & 3,98 & \multirow{2}{*}{$-0,018$} & \multirow{2}{*}{310} & \multirow{2}{*}{0,605} \\
\hline & & Erkek & 3,98 & & & \\
\hline
\end{tabular}

Tablo 6'dan görüldüğü üzere cinsiyete göre hem risk hem de faydaya ilişkin algılanan hiçbir boyut arasında anlamlı farklılıklar bulunamamıştır.

$\mathrm{H}_{7} \mathrm{H}_{8^{\prime}} \mathrm{H}_{9^{\prime}} \mathrm{H}_{10^{\prime}} \mathrm{H}_{11}$ ve $\mathrm{H}_{12}$ hipotezleri varyans analizi ile test edilmiştir. Sonuçlar özet şekilde Tablo 7'de olduğu gibidir:

Tablo 7. Demografik Özelliklere Göre Risk ve Fayda Algılamaları Arasındaki Farklılıklara Ait Varyans Analizleri

\begin{tabular}{|c|l|c|c|c|c|}
\hline \multirow{2}{*}{ Hipotez } & \multicolumn{1}{|c|}{ Risk/Fayda Boyutu } & Değişken & F değeri & $\begin{array}{c}\text { Serbestlik } \\
\text { Derecesi }\end{array}$ & Önem Seviyesi \\
\hline \multirow{3}{*}{$\mathbf{H}_{7}$} & Maddi Risk & Yaş & 2,432 & 3 & 0,065 \\
\cline { 2 - 6 } & Ürüne İlişkin Risk & Yaş & 0,293 & 3 & 0,831 \\
\cline { 2 - 6 } & Alışveriş Sürecine Yönelik Risk & Yaş & 1,853 & 3 & 0,138 \\
\hline \multirow{2}{*}{$\mathbf{H}_{\mathbf{8}}$} & Ürün ve Dağıtım Faydası & Yaş & 1,939 & 3 & 0,123 \\
\cline { 2 - 6 } & Alışveriş Süreci Faydası & Yaş & 3,979 & 3 & $\mathbf{0 , 0 0 8}$ \\
\hline \multirow{3}{*}{$\mathbf{H}_{9}$} & Maddi Risk & Eğitim & 1.133 & 2 & 0,323 \\
\cline { 2 - 6 } & Ürüne Ilişkin Risk & Eğitim & 0,269 & 2 & 0,746 \\
\cline { 2 - 6 } & Alışveriş Sürecine Yönelik Risk & Eğitim & 0,136 & 2 & 0,872 \\
\hline \multirow{2}{*}{$\mathbf{H}_{\mathbf{1 0}}$} & Ürün ve Dağıtım Faydası & Eğitim & 0,887 & 2 & 0,413 \\
\cline { 2 - 6 } & Alışveriş Süreci Faydası & Eğitim & 0,441 & 2 & 0,644 \\
\hline \multirow{3}{*}{$\mathbf{H}_{11}$} & Maddi Risk & Gelir & 0,285 & 4 & 0,887 \\
\cline { 2 - 6 } & Ürüne Ilişkin Risk & Gelir & 0,553 & 4 & 0,697 \\
\cline { 2 - 6 } & Alışveriş Sürecine Yönelik Risk & Gelir & 1,577 & 4 & 0,180 \\
\hline \multirow{2}{*}{$\mathbf{H}_{\mathbf{1 2}}$} & Ürün ve Dağıtım Faydası & Gelir & 1,031 & 4 & 0,391 \\
\cline { 2 - 6 } & Alışveriş Süreci Faydası & Gelir & 0,312 & 4 & 0,870 \\
\hline
\end{tabular}

Tablo 7 incelendiğinde, katılımcıların online alışveriş sürecinin kendisine yönelik algıladıkları faydanın, yaş grupları itibari ile birinin diğerlerinden farklı olduğu görülmektedir. Farklılığın hangi gruptan kaynaklandığını belirlemek üzere Tukey Hsd testi yapılmış farklılığın 20-29 yaş grubu ( $x=4.21$ ) ile $40-49$ yaş grubu $(3,84)$ arasındaki farklııktan kaynaklandığı görülmüştür (sig=0,025). Buna göre genç katılımcıların, orta yaş üstü katılımcılara göre, internetten alışveriş sürecini daha faydalı olarak algılamakta olduğu ifade edilebilir. Bunun dışında diğer demografik özellikler itibariyle katılımcıların online alışverişe yönelik risk ve fayda algılamaları arasında anlamlı farklık bulunamamıştır.

\section{SONUÇ VE ÖNERILER}

Bu çalışmada, katılımcıların, online satın almadan algıladıkları risk ve fayda faktörlerini ortaya koymak için yapılan faktör analizi sonucunda risk faktörleri; maddi risk, ürüne ilişkin risk ve alışveriş sürecine yönelik risk olmak üzere üç başlık altında; fayda faktörleri ise ürün ve dağıtım faydası ve alışveriş süreci faydası 
olmak üzere iki başlık altında toplanmıştır.

Katılımcıların online alışveriş yapma sıklığı ile cinsiyet, yaş, eğitim ve gelir düzeyleri arasında anlamlı bir ilişkinin olup olmadığı ki-kare analizi ile test edilmiştir. Analiz sonucunda online alışveriş yapma sıklığı ile katılımcıların gelir düzeyleri arasında anlamlı bir ilişki olduğu anlaşılmaktadır. Gelir düzeyi arttıkça, online satın alma sayısının da artı̆ğı gözlenmiştir.

Katılımcıların cinsiyet, yaş, eğitim ve gelir düzeylerine göre online alışverişten algıladıkları risk ve fayda arasında anlamlı bir farklılık olup olmadığına yönelik yapılan analiz sonucunda ise genç katılımcıların, orta yaş üstü katılımcılara göre, online alışveriş sürecini daha faydalı olarak algılamakta olduğu bulgusuna ulaşılmıştır. Bu durumun olası bir nedeni, internet deneyimine daha fazla sahip olan genç tüketicilerin teknolojiyi daha iyi kontrol edebildiklerinden online alışverişi daha güvenli bulmaları olabilir. Yine bir diğer neden de genç tüketicilerin interneti daha fazla kullanarak, olası problemleri nasıl önleyeceklerini öğrenmesi ve bu durumun da güven artışına yol açması olabilir (Santana ve Loureiro, 2010). Güven online alışveriş için tüketicileri ikna etmede oldukça önemli bir role sahiptir.

Yapılan çalışmada cinsiyet ve eğitim düzeyinin katılımcıların online alışverişten algıladıkları risk, fayda ve online alışveriş sıklığı üzerinde bir etkisi bulunmamıştır. Cinsiyet açısından bu çalışma bulgusunu destekleyen çok sayıda çalışma vardır. Örneğin, Goldsmith ve Flynn (2004) ve Dillon ve Reif (2004) de yaptıkları çalışmada cinsiyetin online alışveriş yapma kararını etkileyen bir değişken olmadığını bulmuşlardır. Yine çok sayıdaki pazarlama araştırması gelecekte online alışveriş açısından kadınlar ve erkekler arasın- da hiçbir fark olmayacağını ileri sürmüştür (Tariq ve Eddaoudi, 2009).

Online alışveriş davranışı geleneksel alışverişten farklı olduğundan, online alışveriş davranışlarını anlamak için daha fazla çalışma gereklidir. Buna ek olarak, online alışveriş üzerindeki mevcut çalışmaların çoğu sadece tüketicilerin satın alma niyetlerini araştırmış ve online alışverişte karşılaşılan sorunlara net bir çözüm sunmamıştır (Wang vd., 2007). E-ticaretin aşırı büyümesine ve online alışveriş yapan tüketicilerin hızla artmasına rağmen, tüketicilerin online ortamlarda satın alma kararlarını nasıl aldıkları konusu çok az bilinmektedir. Buna ek olarak, birçok insan online alışveriş yaptığında hala hayal kırıklığı yaşamakta ve bu nedenle online alışveriş yapmaya tereddüt etmektedir. Bunun yanında, işletmelerin, tüketicilerin online satın almayı erteleme davranışlarının ve online satın alma konusundaki tereddütlerinin altında yatan nedenleri incelemeleri zorunludur.

Araştırma, yukarıda belirtilen katkılarının yanı sıra bazı kısıtlamaları da içerisinde barındırmaktadır. Çalışma, zaman ve maliyet kısıtlamasından dolayı sadece Trakya Bölgesinde yer alan üniversitelerdeki öğretim elemanları ile gerçekleştirilmiştir. Bunun nedeni, eğitim düzeyi yüksek (en az lisans mezunu) ve nispeten daha homojen bir örnek olan öğretim elemanlarının online alışveriş davranışlarının farklııık gösterip göstermeyeceğinin belirlenmek istenmesidir. Gelecekte yapılacak çalışmalarda, Türkiye'deki diğer üniversitelerdeki öğretim elemanları ya da diğer üniversite çalışanları dahil edilerek araştırmanın kapsamı genişletilebilir. 


\section{KAYNAKLAR}

Akhter, S. H.(2003). Digital divide and purchase intention: Why demographic psychology matters. Journal of Economic Psychology, 24 (3): 321-327.

Akman, I. ve Mishra, A. (2010). Gender, age and income differences in internet usage among employees in organizations. Computers in Human Behavior, 26 (3): 482-490.

Algür, S. ve Cengiz, F. (2011). Türk Tüketicilere Göre Online (Çevrimiçi) Alışverişin Riskleri ve Yararları. Journal of Yasar University, 22 (6): 3666-3680.

Bagdoniene, L. ve Zemblyte, J. (2009). Online Shopping Motivation Factors and Their Effect on Lithuanian Consumers. Economics \& Management, 14: 367-374.

Bhatnagar, A. ve Ghose, S. (2004). Segmenting consumers based on the benefits and risks of internet shopping. Journal of Business Research, 57 (12): 1352-1360.

Candan, B. ve Kurtuluş, K. (2003). İnternet kullanıcılarının gıda, temizlik ve kişisel bakım ürünlerinde sanal alışveriş yapma nedenlerini belirlemeye yönelik pilot bir araştırma. İktisadi ve İdari Bilimler Dergisi, 17 (1-2): 307-321.

Cyr, D. ve Bonanni, C. (2005). Gender and website design in e-business. Int. J. Electronic Business, 3 (6): 565582.

Dillon, T. W. ve Harry, L.R. (2004) Factors influencing consumers' e-commerce commodity purchases, Information Technology, Learning, and Performance Journal, 22 (2): 1-12.

Elibol, H. ve Kesici, B. (2004). Çağdaş işletmecilik açısından elektronik ticaret. Selçuk Üniversitesi Sosyal Bilimler Enstitüsü Dergisi, (11), 303-329.

Makaleye ulaşılabilir adres:

(http://www.sosyalbil.selcuk.edu.tr/sos mak/makaleler/Burcu \%20KES\%C4\%B0C\%C4\%B0\%20 $\% 20 \mathrm{Halil} \% 20 \mathrm{EL} \% \mathrm{C} 4 \% \mathrm{~B} 0 \mathrm{BOL} /$ Elektronik\%20Ticaret $\% 20 . p d f)$. [12.11.2010].

Forsythe, S. ve Shi, B. (2003). Consumer patronage and risk perceptions in Internet shopping. Journal of Business Research, 56 (11): 867-875.

Forsythe, S., Liu, C., Shannon, D., Gardner, L.C. (2006). Development of a scale to measure the perceived benefits and risks of online shopping. Journal of Interactive Marketing, 20 (2): 55-75.

Goldsmith, R.E. ve Flynn, L.R. (2004). Psychological and behavioral drivers of online clothing purchase. Journal of Fashion Marketing and Management, 8 (1): 84-95.

Hair, C. F, Anderson, R. E., Tatham, R. L., Black, V. C. (1998). Multivariate Data Analaysis. 5th edition. New Jersey: Printence Hall.
Hair, C. F, Anderson, R. E., Tatham, R. L., Black, V. C. (2005). Multivariate Data Analaysis. 6th edition. New Jersey: Printence Hall.

Hannah, B. ve Lybecker, K.M. (2010). Determinants of Recent Online Purchasing and the Percentage of Income Spent Online. International Business Research, 3 (4): 60-71.

Hasan, B. (2010). Exploring gender differences in online shopping attitude. Computers in Human Behavior, 26 (4): 597-601.

Hills, P. ve Argyle, M. (2003). Uses of the Internet and their relationships with individual differences in personality. Computers in Human Behavior, 19 (1): 59-70.

Jain, S.K. ve Jain, M. (2011). Exploring impact of consumer and product characteristics on e-commerce adoption: A study of consumers in India. Journal of Technology Management for Growing Economies, 2 (2): 35-64.

Kau, A. K., Tang, Y. E., Ghose, S. (2003). Typology of online shoppers. Journal of Consumer Marketing, 20 (2): 139-156.

Kayış, A. (2008). Güvenilirlik Analizi. İçinde Şerif Kalaycı (Ed.). Spss Uygulamalı Çok Değişkenli İstatistik Teknikleri: 403-424. Ankara: Asil Yayın Dağıtım.

Kurtuldu, H.S., Karataş, M. (2005). İnternet bankacılığında müşteri tercihleri üzerine bir araştırma. I. $\ddot{U}$. Siyasal Bilgiler Fakültesi Dergisi, 33: 29-44.

Kurtuluş, K. (2008). Pazarlama araştırmaları. Genişletilmiş 9. Basım, İstanbul: Filiz Kitapevi.

Liu, C. ve Forsythe, S. (2011). Examining drivers of online purchase intensity: Moderating role of adoption duration in sustaining post-adoption online shopping. Journal of Retailing and Consumer Services, 18 (1): 101-109.

Liu, C. ve Forsythe, S. (2010). Sustaining Online Shopping: Moderating Role of Online Shopping Motives. Journal of Internet Commerce, 9 (2): 83-103.

Özen, H. (2007). İnternetten satın alma davranışı ile risk ve fayda algılamaları arasındaki ilgi. Yayınlanmamıs Yüksek Lisans Tezi. İstanbul Üniversitesi, Sosyal Bilimler Enstitüsü, İstanbul.

Özgüven, N. (2011). Tüketicilerin online alışverişe karşı tutumları ile demografik özellikleri arasındaki ilişkinin analizi. KMÜ Sosyal ve Ekonomik Araştırmalar Dergisi, 13 (21): 47-54.

Porter, C.E. ve Donthu, N. (2006). Using the technology acceptance model to explain how attitudes determine Internet usage: The role of perceived access barriers and demographics. Journal of Business Research, 59 (9): 999-1007. 
Potosky, D. (2007). The Internet knowledge (iKnow) measure. Computers in Human Behavior, 23 (6): 2760 2777.

Richards, J. ve Shen, D. (2006). E-commerce adoption among Chinese consumers: An exploratory study. Joumal of Intemational Consumer Marketing, 18 (3): 33-55.

Rishi, B.J. (2008). An Empirical Study of Online Shopping Behaviour: A Factor Analysis Approach. Journal of Marketing \& Communication, 3 (3): 40-49.

Roman, S. (2010). Relational consequences of perceived deception in online shopping: The moderating roles of type of product, consumer's attitude toward the internet and consumer's demographics. Journal of Business Ethics, 95 (3): 373-391.

Santana, S. ve Loureiro, S. (2010). Assessing benefits and risks of online shopping in Spain and Scotland. Portuguese Journal of Management Studies, 15 (2): 161-172.

Sebastianelli, R., Tamimi, N., Rajan, M. (2008). Perceived quality of online shopping: Does gender make a difference?. Journal of Internet Commerce, 7 (4): 445-469.

Shahrokh, Z.D., Sadaghiani, J.S., Timasi, S.M. (2012). Relation between Iranian students' Demographic and intention to internet purchase. Interdisciplinary Journal of Contemporary Research In Business, 3 (10): 433-441.

Slyke, C.V., Comunale, C.L., Belanger, F. (2002). Gender differences in perceptions of web-based shopping. Communications of The Acm, 45 (7): 82-86.

Sorce, P., Perotti, V., Widrick, S. (2005). Attitude and age differences in online buying. International Journal of Retail \& Distribution Management, 33 (2): 122-132.

$\mathrm{Su}, \mathrm{D}$. ve Huang, X. (2011). Research on online shopping intention of undergraduate consumer in China-based on the theory of planned behavior. International Business Research, 4 (1): 86-92.
Tariq, A.N. ve Eddaoudi, B. (2009). Assessing the effect of trust and security factors on consumers' willingness for online shopping among the urban Moroccans. International Journal of Business and Management Science, 2(1): 17-32.

Teo, T.S.H. ve Tan, J.S. (2002). Senior executives perceptions of business-to-consumer (B2C) online marketing strategies: the case of Singapore. Internet Research: Electronic Networking Applications and Policy, 12 (3): 258275.

Turan, A.H. (2008). "İnternet Alşsverişi Tüketici Davranışını Belirleyen Etmenler: Geliştirilmiş Teknoloji Kabul Modeli (E-TAM) ile Bir Model Önerisi”, Çanakkale Onsekiz Mart Üniversitesi Akademik Bilişim 2008 Konferansı, 30 Ocak-1 Şubat, Çanakkale.

Ugrin, J.M., Pearson, J.M., Odom, M.D. (2007). Profiling cyber-slackers in the workplace: Demographic, cultural, and workplace factors. Journal of Internet Commerce, 6(3): 75-89.

Wang, M.S., Chen, C.C., Chang, S.C., Yang, Y.H. (2007). Effects of online shopping attitudes, subjective norms and control beliefs on online shopping intentions: A test of the theory of planned behaviour. International Journal of Management, 24 (2): 296-302.

Yang, K.C.C. (2005). Exploring factors affecting the adoption of mobile commerce in Singapore. Telematics and Informatics, 22 (3): 257-277.

Yu, J. (2006). Marketing to Chinese consumers on the internet. Marketing Intelligence \& Planning, 24 (4): 380-392.

Zhang, Y. (2005). Age, gender, and Internet attitudes among employees in the business world. Computers in Human Behavior, 21 (1): 1-10. 
